\title{
THE INFLUENCE OF DISINFECTANTS ON MICROBIAL BIOFILMS OF DAIRY EQUIPMENT
}

\author{
Mykola Kukhtyn \\ Department of Food Biotechnology and Chemistry \\ Ternopil I. Pul'uj National Technical University \\ 56 Ruska str., Ternopil, Ukraine, 46001 \\ kuchtynnic@gmail.com \\ Oleksandra Berhilevych \\ Department of Public Health \\ Sumy State University \\ 2 Rymskogo-Korsakova str., Sumy, Ukraine, 40007 \\ bergilevich@ukr.net \\ Khrystyna Kravcheniuk \\ Department of Food Biotechnology and Chemistry \\ Ternopil I. Pul'uj National Technical University \\ 56 Ruska str., Ternopil, Ukraine, 46001 \\ kravchenukx30@gmail.com \\ Oksana Shynkaruk \\ Department of Food Biotechnology and Chemistry \\ Ternopil I. Pul'uj National Technical University \\ 56 Ruska str., Ternopil, Ukraine, 46001 \\ oksankaschynkaruk@gmail.com \\ Yulia Horyuk \\ Department of Infectious and Parasitic Diseases \\ State Agrarian and Engineering University in Podilya \\ 13 Schevchenka str., Kamianets-Podilskyi, Khmelnytskyi region, Ukraine, 32300 \\ goruky@ukr.net \\ Nazariy Semaniuk \\ Department of Microbiology and Virology \\ Lviv National University of Veterinary Medicine and \\ Biotechnologies named after S. Z. Gzhytskyj \\ 50 Pekarska str., Lviv, Ukraine, 79010 \\ Nazariy1980@gmail.com
}

\footnotetext{
Abstract

The aim of the research was to study the features of formation of dairy equipment microflora, the ability of microorganisms to form biofilms on the noncorrosive steel surface with the different roughness and to determine the effectiveness of disinfectants. It was established, that bacteria of Bacillus, Lactobacillus genera of Enterobacteriaceae family are most often extracted from the dairy equipment after the sanitary processing by modern disinfectors, in less number of cases - staphylococci, enterococci, streptococci and pseudomonades. Extracted bacteria form mainly biofilms of the high and middle density. In $100 \%$ of cases biofilms of the high density were formed by Bacillus spp. and Enterococcus faecalis bacteria. It indicates the fact that at the disinfection of the dairy equipment, only stable bacteria that have the ability to produce a biofilm of the high density, remain on its surface.

It was established, that the dairy equipment surface relief, namely roughness, has an influence on the process of biofilm formation in Escherichia coli. On the noncorrosive steel surface with the roughness $0,16 \pm 0,065 \mathrm{mcm}$ Escherichia coli form biofilms of the lower density comparing with the surface with the density $0,63-0,072 \mathrm{mcm}$ during 24 hours at the temperature $17^{\circ} \mathrm{C}$.
} 
It was established, that working solutions of disinfectants P3-ansep CIP, Eco chlor, Medicarine and Maxidez were more effective as to plankton bacteria. Microorganisms, formed in biofilms, turned out stable to these disinfectants. Most effective disinfectant for the influence on bacteria on biofilms is P3-oxonia active - 150. So, the obtained data indicate that for the effective sanitary processing of the dairy equipment it is necessary to use disinfectants that influence bacteria in biofilms.

Keywords: microflora of dairy equipment, biofilm formation, sanitary processing, effectiveness of disinfectants.

\section{Introduction}

The microbiological factor is the one of main factors that influences the quality and safety of milk and milk products. The most important source of milk products microbial contamination is the technological equipment [1-3]. The results of scientific studies indicate that microorganisms survive on the technological equipment due to the extremely important property that is the ability to form biofilms [4-6]. A microbial biofilm - is a formation created of one or several species or genera of bacteria, fixed to the surface and surrounded by the matrix, synthesized by themselves [7, 8]. Biofilms creation - is a process, formed of the following stages: bacteria adhesion to the surface, microbial mass growth, cellular clusters formation, polymer extracellular matrix products formation $[9,10]$. Microbial adhesion - is the main process that depends on the following factors: bacteria specie; surface physical and chemical properties; medium ecological parameters [11,12].

The studies indicate that biofilms of different bacteria, both saprophyte and pathogenic were extracted from the dairy equipment, despite the cleaning and disinfection by modern means [13]. It is connected with the fact that the important feature of bacteria, formed in biofilms, comparing with plankton forms, is the raised resistance to antimicrobial preparations and factors of the environment $[6,14]$. So, even after the sanitary processing of the dairy equipment, microorganisms can remain on its surfaces. Thus, the bacteria ability to biofilm formation of the dairy equipment surface is an important condition of their survival and correspondingly contamination of milk products. So, the study of dairy equipment microflora, bacteria ability to form biofilms, depending on the surface relief and different factors influence, allows to understand the adhesion process deeper and to choose the effective sanitary processing.

The aim of the work was to study the features of the dairy equipment, microorganisms' ability to form biofilms on the noncorrosive steel surface with the different roughness and to determine the effectiveness of disinfectants. It allows to realize the sanitary equipment processing more effectively and to receive products, safe by microoorganisms' content.

\section{Materials and Methods}

\section{1. The studied materials and equipment, used in the experiment}

Samples of raw-milk, washouts from the dairy equipment, tanks-coolers, packing dapparatuses and ready products were selected at three milk-processing enterprises of Ternopyl and Lviv regions (Ukraine). Washouts from the equipment were taken after the sanitary processing, before the beginning and in the middle of the technological process of production (Fig. 1). The washing and cleaning of the equipment were mainly realized automatically, using CIP-settings (Cleaning In Place), made by Atikoro Bobik Yozef (Ukraine). The following disinfectants were used for the sanitary processing: chlorine-containing (P3-ansep CIP, made by Ecolab GmbN, Germany, Eco chlor, made by Cid lines, Belgium, Medicarine, made by Ecolab GmbN, Germany); based on hydrogen peroxide and peracetic acid (P3-oxonia active-150, made by Ecolab GmbN, Germany); with the content of quaternary ammonium salts (Maxidez, made by FSUE "SSC" SRIOCC; Russia); based on nanoparticles of silver (Argenvit, made by SPE "Ecological capital", Ukraine). Samples were delivered to the laboratory in a bag-cooler at the temperature $4-6{ }^{\circ} \mathrm{C}$ during $1-3$ hours. 


\section{Reports on research}

projects
(2017), «EUREKA: Life Sciences»

Number 5
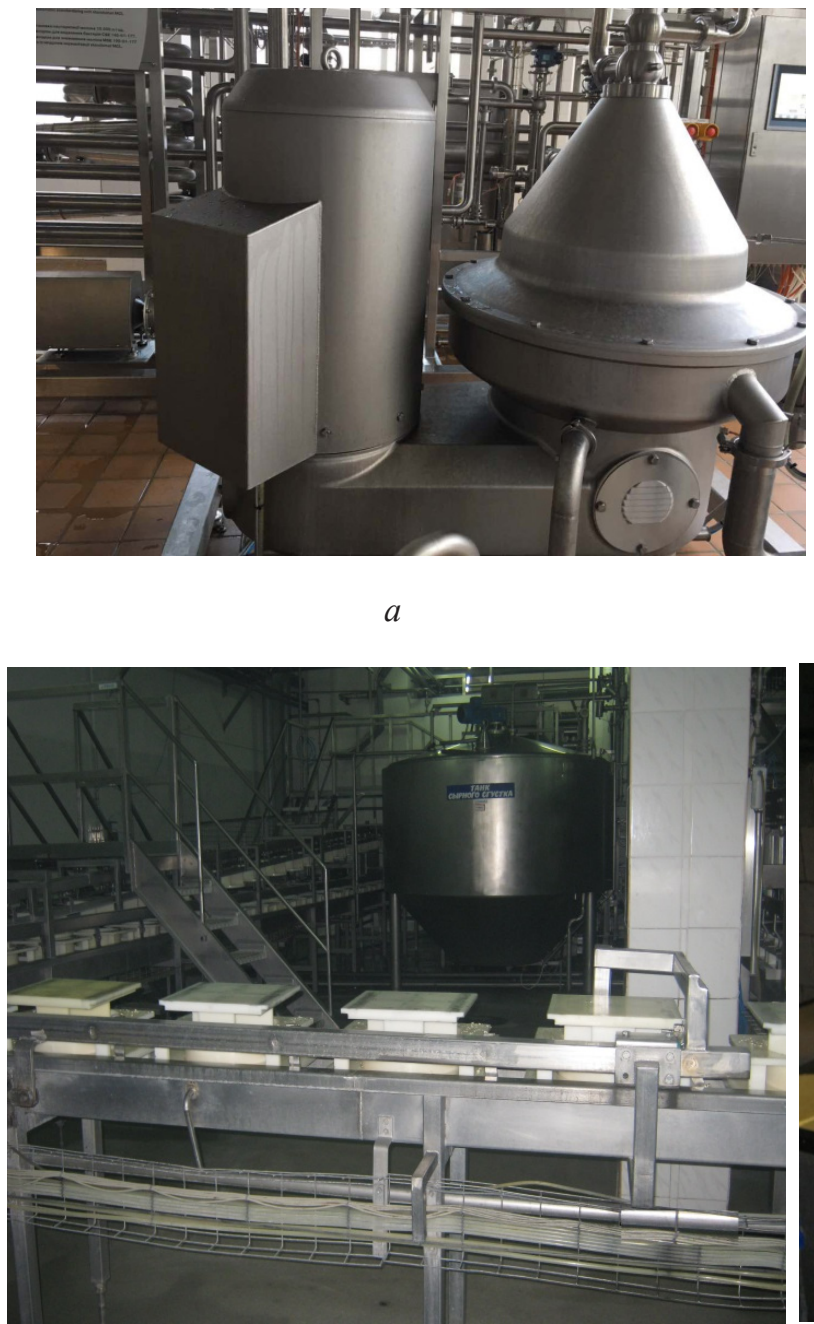

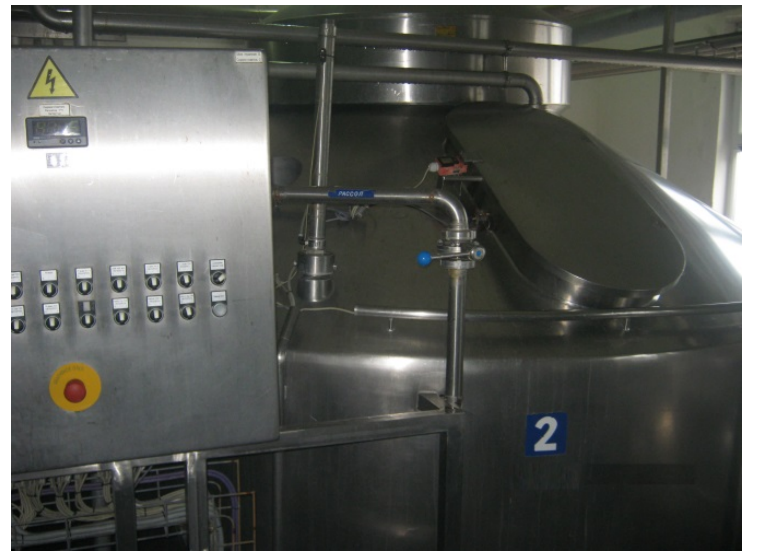

$b$

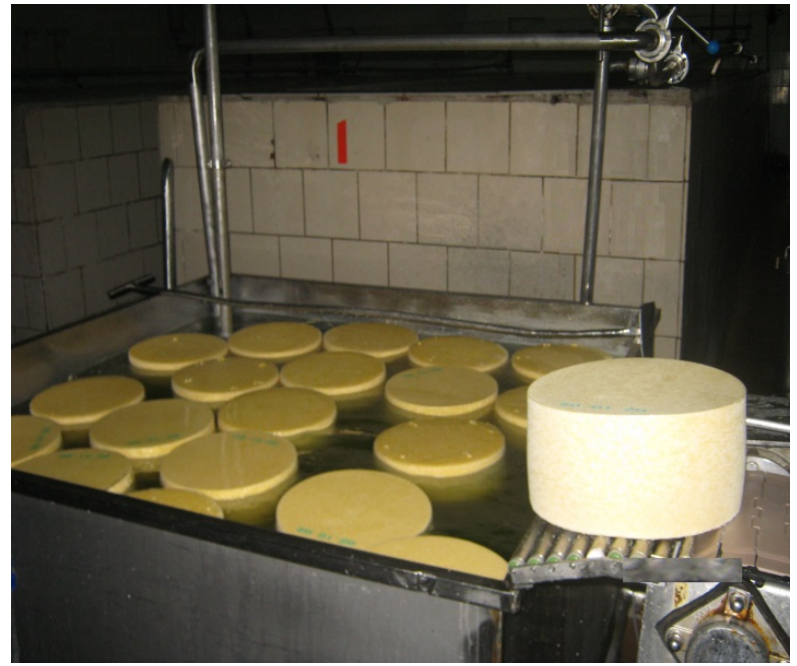

$d$

Fig. 1. Dairy equipment that washouts for the study were taken from: $a$-bactofuge; $b$ - tank for milk fermentation; $c$ - forming apparatus; $d$ - basin for cheese salting

The roughness of surfaces of noncorrosive steel plates was determined by the prophilometer 296. The electronic-microscopic studies of formed biofilms on noncorrosive steel were realized on the raster electronic microscope (REM 106 I, Ukraine) (Fig. 2).

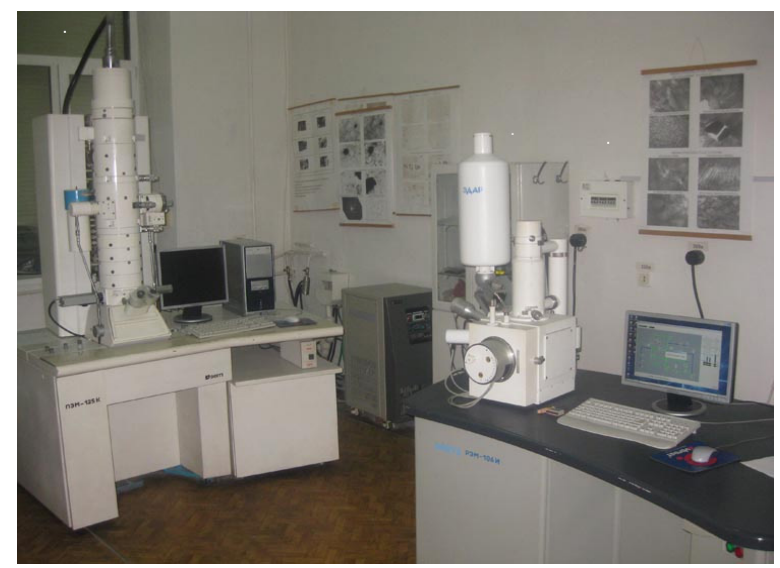

Fig. 2. Raster electronic microscope (REM 106 I) 


\section{2. Methods of determination of microbiological parameters of equipment microflora}

Microorganisms of Lactobacillus genus were extracted on MRS agar medium. The content of enterococci was determined on enterococcus agar medium. The further specific identification was realized using the test system EN-COCCUS-test ("ERBA-Lachema Diagnostika", Czechia). The extraction of bacteria of Staphylococcus genus was realized on the blood medium with $5 \%$ of sodium chloride. The identification of extracted staphylococci was realized on the base of the biochemical activity using commercial test-systems: "STAPHY-test 16', (LACHEMA, Czechia). The content of Enterobacteriaceae and Escherichia coli bacteria families was determined on Endo medium. Microorganisms of Bacillus genus were determined by the inoculation of washes and their solutions on the beef-extract agar with the further incubation at the temperature $30{ }^{\circ} \mathrm{C}$ during 72 hours (that is at classic, standard incubation conditions). Samples were preliminary kept on the water bath at the temperature $85^{\circ} \mathrm{C}$ during $10 \mathrm{~min}$ (to eliminate vegetative forms of bacteria, only spore-creators remain alive). Pseudomonas extraction was realized on the medium with $0,2 \%$ content of $N$-cetylpiridinium chloride, Streptococcus - on Garro medium with $0,1 \%$ water solutiщт of crystal violet. The final identification of bactretia was realized according to the ninth edition of epy bacteria determiner by Berdgey [15].

To determine the density of created biofilms, $5 \mathrm{~cm}^{3}$ of beef-extract broth and $1 \mathrm{~cm}^{3}$ of day test-culture of bacteria in amount of $10^{5} \mathrm{CFU} / \mathrm{cm}^{3}$ were put in sterile plastic Petri dishes, and cultivated at the correspondent temperature during 24 hours. Then dishes were trice washed by the phosphate buffer, biofilms were fixed by ethyl alcohol during 10-15 min. Then dished were colored by $0,1 \%$ water solution of crystal violet during $10-15 \mathrm{~min}$. After that $5,0 \mathrm{~cm}^{3}$ of ethyl alcohol were put in dishes and left for 10-15 min. The optic density of flushing alcohol was determined on the spectrophotometer [16]. At the optic density of the alcohol solution to 0,5 un., the density of created biofilms was considered as low, from 0,5 to 1,0 un. - as middle and at the density more 1,0 un. - high.

The study of epy sensitivity of microorganisms, formed in biofilms, before disinfectants, was realized on 18-24 hour biofilms, cultivated in plastic Petri dishes. Then dishes with biofilms were trice washed by the phosphate buffer and added with $5 \mathrm{~cm}^{3}$ of working solutions of disinfectants and kept for the time, recommended for the sanitary processing for each of them, according to instructions. Then a disinfectant was poured off, and dishes were washed by the phosphate buffer trice again. $5 \mathrm{~cm}^{3}$ of sterile $0,9 \%$ solution of sodium chloride was introduced and biofilm was taken from walls and bottom of the dish by a sterile tampon. Tenfold solutions, inoculated in Petri dishes were prepared of $1,0 \mathrm{~cm}^{3}$ of created suspension. Inoculations were incubated at the temperature 30 ${ }^{\circ} \mathrm{C}$ during 48 hours (that is at the optimal temperature and time, necessary for colonies creation) and the number of bacteria in the biofilm was determined.

The determination of plankton microorganisms to disinfectants was realized as following. $10 \mathrm{~cm}^{3}$ of working solutions of means with a correspondent concentration were introduced in test tubes and added with $0,1 \mathrm{~cm}^{3}-1$ bil batch of studied bacteria. The exposition was set depending on the time, recommended for the sanitary processing of the equipment by this means $[4,12]$. Then $1,0 \mathrm{~cm}^{3}$ of the test tube content was taken and tenfold solutions were prepared; they were introduced in Petri dishes in $1 \mathrm{~cm}^{3}$ and poured with beef-extract agar. Inoculations were cultivated in the thermostat at the temperature $30^{\circ} \mathrm{C}$ (that is optimal) and the result was calculated in 48 hours, necessary for colonies formation. The obtained results of research were statistically processed using Statistika 6 program. The difference was considered as reliable at $\mathrm{P}<0,05$.

\section{Results}

The results of the study of microflora, extracted from the dairy equipment and ready products at milk-processing enterprises of Ternopyl and Lviv regions demonstrated the following. The equipment contamination by bacteria of Bacillus, Lactobacillus genera of Enterobacteriaceae family takes place most often. Microorganisms of Enterococcus, Staphylococcus, Streptococcus and Pseudomonas genera were extracted from the equipment less often. So, the studies established that even at the standard sanitary processing, the diary equipment is not sterile, and microorganisms that forms microflora of ready products, are extracted from its surface. 
For studying the possibility of resistance to the external factors, there was determined the density of biofilms of main bacteria of dairy equipment microflora. Table 1.

Table 1

The density of biofilms of bacteria, extracted from the dairy equipment, $\%, M \pm m, n=170$

\begin{tabular}{ccc}
\hline Bacteria extracted from the equipment & $\begin{array}{c}\text { Number of cultures that formed } \\
\text { the high density biofilm, } \%\end{array}$ & Biofilms density, un. \\
\hline Pseudomonas aeruginosa & $74,31 \pm 4,83$ & $1,57 \pm 0,10$ \\
Escherichia coli & $82,45 \pm 4,77$ & $1,75 \pm 0,14$ \\
Enterococcus & 100 & $1,60 \pm 0,11$ \\
- faecalis & $78,64 \pm 3,92$ & $1,74 \pm 0,13$ \\
- faecium & $86,87 \pm 4,25$ & $1,77 \pm 0,11$ \\
Staphylococcus aureus & 100 & $1,13 \pm 0,08$ \\
Bacillus cereus & $28,53 \pm 1,78$ & $1,21 \pm 0,09$
\end{tabular}

From Table 1 we can wee, that the density of microbial biofilms has the important influence on microorganisms' survival on the dairy equipment surfaces. Thus, the most dense biofilms (1,75-1,77 un) were formed by bacteria of Bacillus cereus and Enterococcus faecalis genera in $100 \%$ of cases. The golden staphylococcus, colon bacillus and pseudomonades formed biofilms with the density from 1,57 to 1,74 un in $74,31-86,87 \%$ of cases. Least dense biofilms (1,13-1,21 un) formed by bacteria of Streptococcus agalactiae and Lactobacillus spp., genera, were extracted in $28,53-57,36 \%$ of cases.

So, dense biofilms formation testifies to the fact that bacteria in a formed biofilm can remain on internal surfaces of the dairy equipment for a long time and to play the main role in the contamination of products.

Noncorrosive steel of the different roughness is mainly used for the dairy equipment. The study of the process of biofilm formation was realized using Escherichia coli bactery. The results of the ability to form biofilms on noncorrosice steel by the main representatives of dairy equipment microflora with the different roughness during 24 hours are presented on Fig. 3.

The research results, presented on Fig. 3, demonstrated that the less roughness value, the slower the process of the initial fixation to the surface is. But this regularity continues only 24 hours at the incubation at the temperature $17^{\circ} \mathrm{C}$.

Thus, the realized researches indicate that the dairy equipment that directly contacts with the product must have such surface roughness that obstacles and detains the process of both bacteria initial adhesion and further biofilm formation. The formed dense biofilm will influence the effectiveness of the sanitary processing by disinfectants.

The following data were obtained at studying the influence of disinfectants, used for the dairy equipment sanitation at milk-processing enterprises. Preparations, included such active substances as quaternary ammonium compounds, chlorine, nanoparticles of silver, manifested the effectiveness to bacteria plankton forms. At the same time these preparations were weakly active or had no effect on film-creating bacteria forms. It was also established, that the sanitary means that contained peracetic acid and hydrogen peroxide had the positive effect on bacteria plankton forms and practically all biofilms. The means turned out to be ineffective only to cells of blue-purulent bacillus, formed in biofilms. 


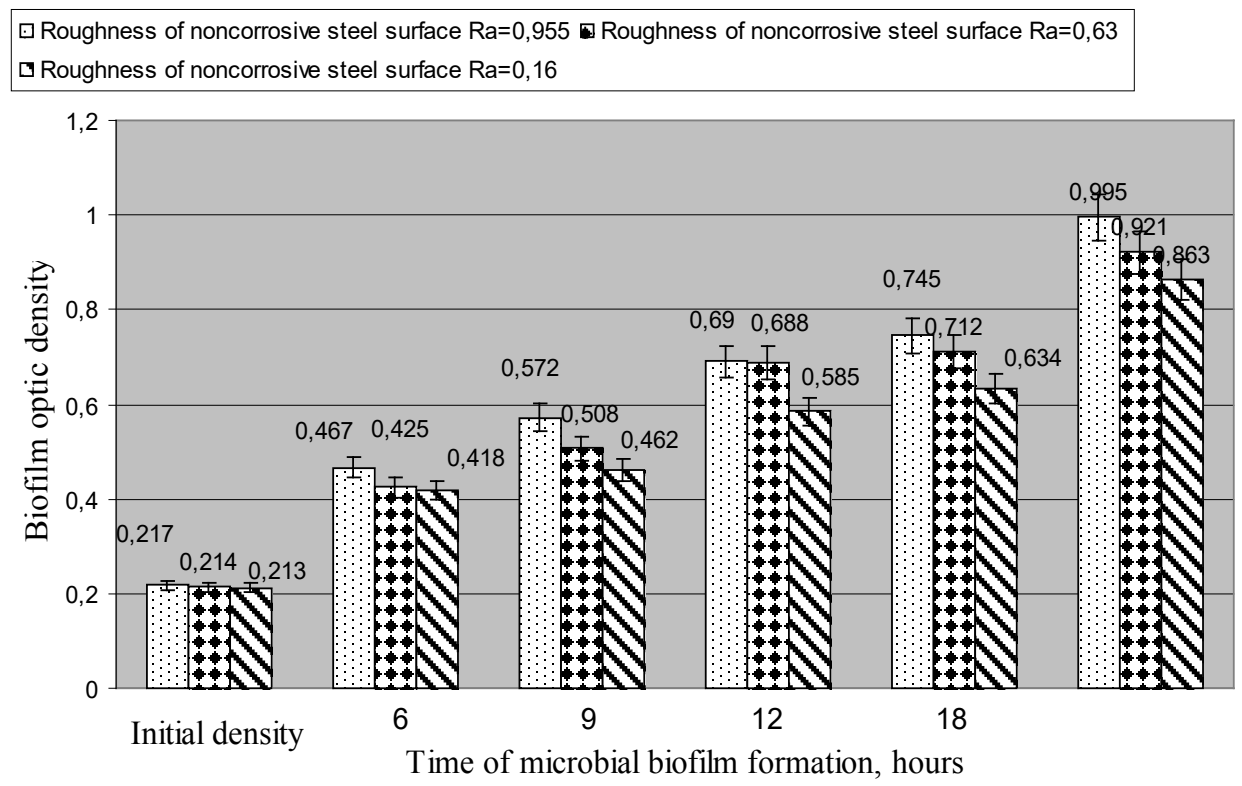

Fig. 3. The process of biofilm formation by Escherichia coli strain on noncorrosive steel surface during 24 hours

Thus, the realized researches indicate that the established minimal bactericidal concentration of a means on plankton test-cultures of microorganisms cannot be a parameter of the dairy equipment sanitary processing effectiveness. At determining the effectiveness of disinfectors, it is necessary to choose such working concentration that acts not only on plankton forms but also on bacteria in formed biofilms. Alongside with it, for the effective sanitary processing to the diary equipment, it is necessary to determine the adaptation of extracted microflora to disinfectants and to change means each 6-12 of their use, according to the results of experiments.

\section{Conclusions}

It was established, that at the technology of milk products, microflora forms on the dairy equipment due to the creation of high density biofilms. In $100 \%$ of cases high density biofilms were formed by Bacillus spp. and Enterococcus faecalis bacteria. Bacteria of Staphylococcus, Pseudomonas and Escherichia genera created high density biofilms in 74,3-86,8 \% of cases.

It was established, that the relief of the dairy equipment surface, namely roughness, has the influence on biofilm formation in Escherichia coli. Escherichia coli form biofilms of the lower density on the noncorrosive steel surface with the roughness $0,16 \pm 0,065 \mathrm{mcm}$, comparing with the surface with the roughness $0,63-0,072 \mathrm{mcm}$ during 24 hours at the temperature $17^{\circ} \mathrm{C}$. It testifies to the fact that the effective sanitary processing of the equipment must take place immediately after the finish of the technological process for preventing high density biofilms formation.

It was established, that means that contain peracetic acid and hydrogen peroxide turned out most effective for destructing microbial biofilms, formed on the dairy equipment. At the same time disinfectants, based on chlorine and quaternary ammonium compounds turned out ineffective as to biofilm forms of microorganisms.

So, biofilms on the dairy equipment - is the one of sources of milk products contamination, and it is necessary to consider this problem complexly to overcome it. It is necessary to study the biofilms matrix content, influence of different biocytes and enzymes on it, to elaborate the equipment with anti-adhesive properties.

\section{References}

[1] Aires, G. S. B., Walter, E. H. M., Junqueira, V. C. A., Roig, S. M., Faria, J. A. F. (2009). Bacillus cereus in Refrigerated Milk Submitted to Different Heat Treatments. Journal of Food Protection, 72 (6), 1301-1305. doi: 10.4315/0362-028x-72.6.1301 
[2] Walkling-Ribeiro, M., Rodriguez-Gonzalez, O., Jayaram, S., Griffiths, M. W. (2011). Microbial inactivation and shelf life comparison of "cold" hurdle processing with pulsed electric fields and microfiltration, and conventional thermal pasteurisation in skim milk. International Journal of Food Microbiology, 144 (3), 379-386. doi: 10.1016/j.ijfoodmicro.2010.10.023

[3] Petrus, R. R., Loiola, C. G., Oliveira, C. A. F. (2010). Microbiological Shelf Life of Pasteurized Milk in Bottle and Pouch. Journal of Food Science, 75 (1), 36-40. doi: 10.1111/j.1750-3841.2009.01443.x

[4] Marchand, S., De Block, J., De Jonghe, V., Coorevits, A., Heyndrickx, M., Herman, L. (2012). Biofilm Formation in Milk Production and Processing Environments; Influence on Milk Quality and Safety. Comprehensive Reviews in Food Science and Food Safety, 11 (2), 133-147. doi: 10.1111/j.15414337.2011.00183.x

[5] Bremer, P. J., Seale, B., Flint, S., Palmer, J. (2009). Biofilms in dairy processing. Biofilms in the food and beverage industries. Oxford-Cambridge-New Delhi: Woodhead Publishing Limited, 396-431. doi: 10.1533/9781845697167.4.396

[6] Seale, B., Bremer, P., Flint, S., Brooks, J., Palmer, J. (2015). Overview of the Problems Resulting from Biofilm Contamination in the Dairy Industry. Biofilms in the Dairy Industry. Chichester: John Wiley \& Sons, Ltd, 49-64. doi: 10.1002/9781118876282.ch4

[7] Oliveira, N. M., Martinez-Garcia, E., Xavier, J., Durham, W. M., Kolter, R., Kim, W., Foster, K. R. (2015). Correction: Biofilm Formation As a Response to Ecological Competition. PLOS Biology, 13 (8), e1002232. doi: 10.1371/journal.pbio.1002232

[8] Monds, R. D., O'Toole, G. A. (2009). The developmental model of microbial biofilms: ten years of a paradigm up for review. Trends in Microbiology, 17 (2), 73-87. doi: 10.1016/j.tim.2008.11.001

[9] Finkel, J. S., Mitchell, A. P. (2010). Genetic control of Candida albicans biofilm development. Nature Reviews Microbiology, 9 (2), 109-118. doi: 10.1038/nrmicro2475

[10] Zhao, K., Tseng, B. S., Beckerman, B., Jin, F., Gibiansky, M. L., Harrison, J. J. et. al. (2013). Psl trails guide exploration and microcolony formation in Pseudomonas aeruginosa biofilms. Nature, 497 (7449), 388-391. doi: 10.1038/nature12155

[11] Langsrud, S., Moen, B., Moretro, T., Loype, M., Heir, E. (2016). Microbial dynamics in mixed culture biofilms of bacteria surviving sanitation of conveyor belts in salmon-processing plants. Journal of Applied Microbiology, 120 (2), 366-378. doi: 10.1111/jam.13013

[12] Krushelnytska, N. V. (2013). Influence of $\mathrm{pH}$ on the ability to form microbial biofilms by microorganisms isolated from milking equipment and raw milk. Scientific and Technical Bulletin of the Institute of Animal Biology and the State Scientific-Research Control Institute of Veterinary Preparations and Feed Additives, 14, (3-4), 82-86. Available at: http://nbuv.gov.ua/UJRN/Ntbibt_2013_14_3-4_17

[13] Shaheen, R., Svensson, B., Andersson, M. A., Christiansson, A., Salkinoja-Salonen, M. (2010). Persistence strategies of Bacillus cereus spores isolated from dairy silo tanks. Food Microbiology, 27 (3), 347-355. doi: 10.1016/j.fm.2009.11.004

[14] Ranieri, M. L., Huck, J. R., Sonnen, M., Barbano, D. M., Boor, K. J. (2009). High temperature, short time pasteurization temperatures inversely affect bacterial numbers during refrigerated storage of pasteurized fluid milk. Journal of Dairy Science, 92 (10), 4823-4832. doi: 10.3168/jds.2009-2144

[15] Hoolta, J., Kriga, N., Snita, P. et. al. (1997). Determinant of Bergy bacteria. In 2 Vol. Moscow: Mir, 799.

[16] Stepanovic, S., Vukovic, D., Dakic, I., Savic, B., Svabic-Vlahovic, M. (2000). A modified microtiter-plate test for quantification of staphylococcal biofilm formation. Journal of Microbiological Methods, 40 (2), 175-179. doi: 10.1016/s0167-7012(00)00122-6 